\title{
Quality Signal Impacts on Firm Level Production: Evidence from the Beer Industry
}

\author{
Mitch Kunce ${ }^{1}$
}

\begin{abstract}
The intuitive nature of signaling theory in part helps explain its pervasiveness. The usefulness of a signal depends on the extent to which the signal corresponds with the sought after quality of the signaler. Herein, we examine a singular quality signal from the beer industry-winning a coveted Great American Beer Festival $(\mathrm{GABF})$ medal. To provide an assessment of the quantitative impact of winning a GABF medal, this paper exploits a unique and expansive unbalanced panel of timeseries, cross-section data from 1989-2012. Firm specific production changes are merged with the GABF medal winner database. Results from a two-way fixedeffects specification finds no significant relationship between winning a GABF medal or medals and changes in a brewery's output. Interestingly, it appears that the GABF quality signal applies more to the brewer than the brewery.
\end{abstract}

JEL classification numbers: D12, L81, M31.

Keywords: Quality signals, production, information asymmetry.

${ }^{1}$ DouglasMitchell Econometric Consulting, Laramie, WY USA

Article Info: Received: June 18, 2021. Revised: July 8, 2021.

Published online: July 15, 2021. 


\section{Introduction}

Skiers coming off the steep slopes of Snow King or heading south to town from the Village often find themselves in the mezzanine overlooking the brewhouse at the Snake River Brewing Company in Jackson, Wyoming USA. It is difficult not to notice dozens of Brewers Association (BA) ${ }^{2}$ award banners hanging from the walls and rafters - Gold Medal, Zonker Stout, 1999 - Gold Medal, Snake River Lager, 2000 - Back to back Small Brewing Company of the year, 2000 \& 2001, etc. These banners represent more than competition displays, they are signals of underlying product quality (in the spirit of Spence 1973, 2002). Each fall, since 1982, the Brewers Association puts on the Great American Beer Festival (GABF) in Colorado. The competition began in 1983 where winners were decided by a consumer poll. The first winner was Sierra Nevada Brewing Company with their flagship Pale Ale. In 1987 the competition changed to a judged event - 38 medals were awarded over 13 style categories. Fast forward to 2020, the pandemic year competition garnered 8,806 entries from 1,720 breweries awarding 272 medals (GABF 2021).

According to the Brewers Association,

"The professional judge panel awards gold, silver or bronze medals that are recognized around the world as symbols of brewing excellence. These awards are among the most coveted in the industry and heralded by the winning brewers in their national advertising." (GABF 2021)

Participation in this premier competition is not costless to the breweries. With over 8,000 breweries in the U.S. currently, there is a surplus of entrants yearning to compete. The GABF online ${ }^{3}$ entry registration has been characterized as a spirited game of chance (Meyer 2019). Moreover, each style entry requires a specific fee ${ }^{4}$ along with the cost of transporting (over one month before the event) the packaged beer to the competition's location, Denver, CO. Breweries can ensure entry by becoming a 'Featured Sponsor' making a lump sum donation to the BA based on their annual production (in 31 gallon barrels). Accordingly, the BA provides medal winners with guidance on how to promote their awards to yield the utmost impact (Kunce 2021).

The quality signal described above is recognized as default and sale-independent (Kirmani and Rao 2000). Default-independence refers to signals where the monetary outlay is independent of whether the firm defaults on its quality claim. Sale-independent signals involve expenditures that occur regardless of whether

\footnotetext{
2 The Association of Brewers Incorporated is a 501(c)(6) trade organization based in Boulder, CO. The Association of Brewers and the Brewers' Association of America merged in 2005 forming the dba Brewers Association (BA). The BA claims that roughly two-thirds of the breweries in the U.S. are dues paying members (BA 2021).

3 Online registration was incrementally introduced from the mid to late 2000s.

${ }^{4}$ If brewers are not members of the BA, fees are roughly doubled. In most cases, becoming a member of the BA lowers specific entry cost.
} 
anyone purchases the product. The GABF signal invokes one more layer of complexity, winning. As described above, 1,720 breweries successfully entered the 2020 competition, only 240 (14\%) were awarded medals. Historically, the winning proportion of breweries entered is roughly $25 \%$. Efficacious signals must be readily observable to consumers, mere participation in the GABF lacks the needed perceptible message (Connelly et al 2011). The GABF medal signal appears rational if future sales are generated, in other words, does winning medals signal quality (i.e. signal fit) and does this now observed quality generate future output increases? Herein we intend to shed much needed light on this salient question. Although the empirical literature on the advertising - quality - price relationships is substantial (see Kirmani and Rao 2000; Ackerberg 2003; Bagwell 2007; Connelly et al 2011 for extensive reviews) the literature on how quality signals impact firm specific output is inadequate (Yang 2021). A small subset of the advertising signal literature focuses on expert review effects on consumer demand. Most noteworthy and fairly related to the analysis herein is a study by Friberg and Grönqvist (2012) involving the wine industry. They find evidence that favorable expert reviews increase wine sales from the Swedish state-owned liquor monopoly, Systembolaget. The positive sales response fades with time ( 20 weeks) and the authors reveal no significant negative effects from unfavorable reviews.

To provide an assessment of the quantitative impact of winning a GABF medal, this paper exploits a unique and expansive unbalanced panel of time-series, crosssection data from 1989 -2012. Firm specific production changes are merged with the BA's GABF medal winner database. Results from a two-way fixed-effects specification finds no significant relationship between winning a GABF medal or medals and changes in a brewery's output. The balance of this paper is divided into three sections. Section 2 describes the unique data set and discusses the empirical model and econometric issues. In section 3, results are presented and interpreted with conclusions and implications drawn in section 4.

\section{Data and empirical model}

A hidden gem was uncovered while perusing the supplementary materials accompanying the Elzinga, Tremblay and Tremblay (2015) paper. As highlighted in bold in Appendix B herein, Elzinga and Tremblay squared procured an expansive data set of firm level annual production data. The firm specific data was sourced from The New Brewer, a periodical published by the Brewers Association. After merging the twelve spreadsheets provided, the raw data set supplied 23,360 observations of annual production from just under 2,600 breweries. Two filters were applied to the raw data set - observations with missing production were dropped and firm groups with less than four consecutive time periods (years) were omitted. ${ }^{5}$ Missing production data is not a result of censoring and simply appears to be

\footnotetext{
5 When panels are unbalanced, there is a large degree of complication in the computation of estimates. In order to mitigate potential matrix rank problems, firm groups are structured with four or more consecutive annual time periods.
} 
random. Post filtering, 22,211 production observations from 2,462 breweries across all 50 states and the District of Columbia for the time period 1989-2012 remained. The Brewers Association maintains a searchable database for all GABF medals awarded from 1983 to date at the website http://www.greatamericanbeerfestival.com. Information available for query is brewery by name, brewery location by city and state, name of winning beer, style category and medal awarded by year. Figure 1 depicts total medals awarded ${ }^{6}$ and the number of winning breweries for each year noted. As shown, many breweries are fortunate enough to be awarded multiple medals in a given year. Accordingly, we search to answer the question - does winning a medal or multiple medals in a given year $t$ impact changes in a brewery's output from $t$ to $t+1 ?^{7}$

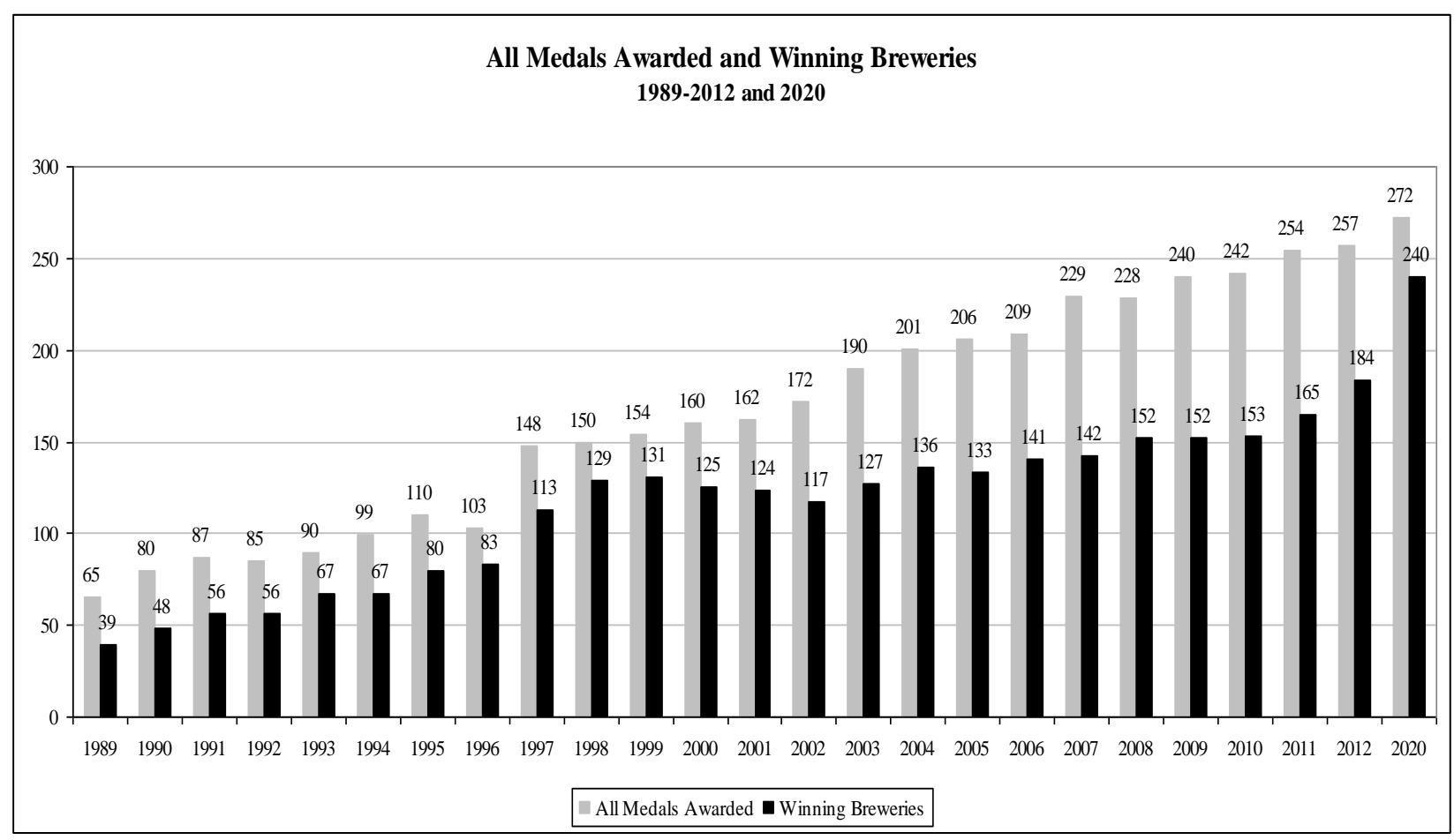

Figure 1: Medals Awarded and Winning Breweries

6 Pro-Am and Collaboration Brewing medals included.

7 Impacts of a medal or medals awarded in time $t$ on production changes from $t$ to $t+4$ (accounting for a delayed effect) were also analyzed. This specification resulted in a substantial loss of degrees of freedom with overall estimates being comparable. 
Specifically, the model estimated is,

$$
C H P_{i t}=\alpha+\beta M_{i t}+\mu_{i}+\lambda_{t}+v_{i t}
$$

where $C H P_{i t}$ is the percentage change in production for brewery $i$ from year $t$ to $t+$ $1 ; \alpha$ is a scalar intercept term; $\beta$ is the medal coefficient; $M_{i t}$ takes the value 1 if brewery $i$ wins one or more medals ${ }^{8}$ in year $t, 0$ otherwise; $\mu_{\mathrm{i}}$ denotes firm specific effects; $\lambda_{\mathrm{t}}$ represents year effects and $v_{i t}$ is the remainder stochastic disturbance term. Note that $\mu_{\mathrm{i}}$ is time-invariant and captures unobserved brewery specific effects. Additionally, $\lambda_{\mathrm{t}}$ will capture any unobserved time-varying factors common to all breweries.

The properties of estimators for equation (1) depend on whether the latent firm and year effects are specified as fixed but unknown differences in the constant term or assumed randomly drawn and uncorrelated with other regressors. A virtue of the fixed effects estimator is that estimates are unbiased and consistent regardless of any correlation between the effects and other regressors. Conversely, fixed effects may not be fully efficient since variation across firms and time periods are ignored. Herein, fixed effects estimation seems appropriate, moreover, $\beta$ represents an additional shift in the intercept term. Table 1 describes, provides data sources and depicts descriptive statistics for variables in equation (1).

\section{Table 1: Description of Variables and Descriptive Statistics}

\begin{tabular}{|l|c|}
\hline \multicolumn{1}{|c|}{ Variable } & \multicolumn{1}{c|}{ Definition and Source } \\
\hline $\begin{array}{l}\text { Annual firm production in 31 gallon } \\
\text { barrels. 2,462 breweries represented. } \\
\text { Mean 5,793, STD 47,845. }\end{array}$ & $\begin{array}{l}\text { Database from Elzinga et al (2015) referred } \\
\text { to on page 271, see Appendix B for details. }\end{array}$ \\
\hline $\begin{array}{l}C H P \text { - percentage change in production } \\
\text { year } t \text { to } t+1 .\end{array}$ & \multicolumn{1}{c|}{ Calculation herein. } \\
Mean 32.49, STD 228.85. & \\
\hline $\begin{array}{l}M \text { - Medals dummy variable, one or } \\
\text { more medals awarded to a firm in a } \\
\text { year }=1,0 \text { otherwise. } \\
\text { Mean 0.095, STD } 0.293\end{array}$ & http://www.greatamericanbeerfestival.com \\
\hline
\end{tabular}

Converting the left-hand side to annual percentage changes reduces the sample observations from 22,211 to 19,749 . The medals dummy mean of 0.095 translates to 1,872 firm medal-years. A firm medal-year includes the occurrence of the same brewery winning medals in multiple years.

\footnotetext{
8 In an alternative specification, the medals variable was split to include a dummy for firms winning more than two medals in the same year, overall results were effectively unchanged.
} 


\section{Estimation results}

Results from two-way fixed-effects estimation of equation (1) are presented in Table 2. ${ }^{9}$

Table 2: Two-Way Fixed Effects Estimates*

\begin{tabular}{|l|l|}
\hline Scalar Constant $(\mathrm{t})$ & $32.48(20.39)$ \\
\hline Medals $(\mathrm{t})$ & $0.12(0.20)$ \\
\hline R-Squared & 0.29 \\
\hline Observations & 19,749 \\
\hline Durbin-Watson & 1.98 \\
\hline F-Test, Firm Effects vs Pooled OLS (P-Value) (df) & $2.71(0.00)(2,461,17,286)$ \\
\hline F-Test, Adding Year Effects vs One-Way Model (P-Value) (df) & $2.64(0.00)(22,17,264)$ \\
\hline $\begin{array}{l}\text { *Estimated using the White heteroscedasticity consistent covariance matrix. } \\
\text { Firm and Year effects are numerous and omitted from the table. }\end{array}$ \\
\hline
\end{tabular}

Estimates confirm brewery and year heterogeneity and verify the importance of controlling for unobservable firm and year effects. First, the test statistic F $(2,461$, $17,286)=2.71$ is sufficient to reject the null hypothesis of firm homogeneity at the $<1 \%$ level. Second, the $\mathrm{F}(22,17,264)=2.64$ statistic favors the two-way model over the one-way specification, again at the $<1 \%$ level. The medals effect is statistically insignificant at any conventional level. Winning GABF awards does not impact the change in production at the firm level.

From the competition's inception in 1983 to 2012, breweries in four states have been awarded roughly two-thirds of the cumulative GABF medals; California, Colorado, Oregon and Wisconsin. This dominance may indicate some type of spatial/regional effect. To examine this, the data was sorted by state with separate regressions specified for each of the four states mentioned. Table 3 below presents the descriptive statistics for each of the four states. Table 4 below shows the two-way fixed-effects estimates for each state specification. Estimates reinforced the importance of controlling for latent firm and year effects in each specification. The medals variable, again, is statistically insignificant at conventional levels for each state. While the medals t-statistic improved across state-specific models, convincing evidence that winning GABF medals impacts changes in firm output is negligible.

9 A referee suggested that pooled OLS and Random Effects estimates should be presented for comparison. These results are provided in Appendix A. No compelling evidence in favor of the Random Effects estimates is present. 


\section{Conclusion}

Findings herein are consistent with industry experience. In a recent interview with several influential industry insiders, reasons breweries compete in the GABF have less to do with signaling quality to affect future sales and more to do with brewer acclaim and brewer networking (Alworth 2017). Gary Fish, founder of Deschutes Brewing in Oregon, summarizes the conventional stance,

"Over the years, we have won our fair share of GABF hardware - we have enjoyed every one. We have rarely used these awards for marketing purposes, although we have done it. We enjoy our victories like everyone else, but what it does for sales? Who knows."

Long time Firestone Walker brewmaster Matt Brynildson pivots the signaling focus to the brewer,

"One could argue that having a great brewer at the helm of a brewery is the real key to success and that the awards are simply the artifact from that sound business move..."

Brewmaster Phil Leinhart of Ommegang Brewing in New York, provided the best one-liner on why they compete in the GABF, "It can be useful to see how you stack up." Interestingly, it seems that the GABF quality signal applies more to the brewer than the brewery. Brewery output is unaffected yet brewer acclaim appears elevated. In the true spirit of Spence (1973), future work in this area could pivot toward examining a medal winning brewer's success in the labor market. Does winning a GABF medal signal that a brewer is a high quality candidate when seeking new employment? Do medal winning brewers make more money than their peers? Addressing these questions by examining labor market perceptions and firm's incentives may lead to a richer understanding of this particular type of quality signal. 
Table 3: Select States Descriptive Statistics

\begin{tabular}{|c|c|c|}
\hline \multicolumn{3}{|l|}{ California } \\
\hline $\begin{array}{l}\text { Annual firm production in } 31 \text { gallon barrels. } \\
342 \text { breweries represented. }\end{array}$ & Mean 6,779 & STD 44,675 \\
\hline$C H P$ - Percentage change in production, year $t$ to $t+1$. & Mean 23.61 & STD 184.99 \\
\hline$M$ - Medals dummy variable, 353 medal-years. & Mean 0.12 & STD 0.32 \\
\hline \multicolumn{3}{|l|}{ Colorado } \\
\hline $\begin{array}{l}\text { Annual firm production in } 31 \text { gallon barrels. } \\
161 \text { breweries represented. }\end{array}$ & Mean 6,621 & STD 42,100 \\
\hline$C H P$ - Percentage change in production, year $t$ to $t+1$. & Mean 36.96 & STD 361.72 \\
\hline$M$ - Medals dummy variable, 252 medal-years. & Mean 0.18 & STD 0.39 \\
\hline \multicolumn{3}{|l|}{ Oregon } \\
\hline $\begin{array}{l}\text { Annual firm production in } 31 \text { gallon barrels. } \\
137 \text { breweries represented. }\end{array}$ & Mean 9,966 & STD 42,966 \\
\hline$C H P$ - Percentage change in production, year $t$ to $t+1$. & Mean 27.36 & STD 109.43 \\
\hline$M$ - Medals dummy variable, 114 medal-years. & Mean 0.10 & STD 0.30 \\
\hline \multicolumn{3}{|l|}{ Wisconsin } \\
\hline $\begin{array}{l}\text { Annual firm production in } 31 \text { gallon barrels. } \\
92 \text { breweries represented. }\end{array}$ & Mean 5,374 & STD 20,486 \\
\hline$C H P$ - Percentage change in production, year $t$ to $t+1$. & Mean 35.21 & STD 218.93 \\
\hline$M$ - Medals dummy variable, 79 medal-years. & Mean 0.10 & STD 0.30 \\
\hline
\end{tabular}


Table 4: Select State Two-Way Fixed-Effects Estimates*

\begin{tabular}{|c|c|}
\hline \multicolumn{2}{|l|}{ California } \\
\hline Scalar Constant (t) & $22.00(6.68)$ \\
\hline Medals (t) & $13.78(1.21)$ \\
\hline R-Squared & 0.30 \\
\hline Observations & 3,022 \\
\hline Durbin-Watson & 2.00 \\
\hline F-Test, Firm Effects vs Pooled OLS (P-Value) (df) & $3.24(0.00)(341,2679)$ \\
\hline F-Test, Adding Year Effects vs One-Way Model (P-Value) (df) & $3.06(0.00)(22,2657)$ \\
\hline \multicolumn{2}{|l|}{ Colorado } \\
\hline Scalar Constant $(\mathrm{t})$ & $32.48(3.32)$ \\
\hline Medals (t) & $24.78(0.95)$ \\
\hline R-Squared & 0.32 \\
\hline Observations & 1,393 \\
\hline Durbin-Watson & 1.99 \\
\hline F-Test, Firm Effects vs Pooled OLS (P-Value) (df) & $3.44(0.00)(160,1231)$ \\
\hline F-Test, Adding Year Effects vs One-Way Model (P-Value) (df) & $3.13(0.00)(22,1209)$ \\
\hline \multicolumn{2}{|l|}{ Oregon } \\
\hline Scalar Constant $(\mathrm{t})$ & $26.13(7.97)$ \\
\hline Medals (t) & $12.61(0.96)$ \\
\hline R-Squared & 0.23 \\
\hline Observations & 1,172 \\
\hline Durbin-Watson & 1.95 \\
\hline F-Test, Firm Effects vs Pooled OLS (P-Value) (df) & $2.18(0.00)(136,1034)$ \\
\hline F-Test, Adding Year Effects vs One-Way Model (P-Value) (df) & $1.90(0.00)(22,1012)$ \\
\hline \multicolumn{2}{|l|}{ Wisconsin } \\
\hline Scalar Constant $(\mathrm{t})$ & $31.73(3.89)$ \\
\hline Medals (t) & $35.65(1.10)$ \\
\hline R-Squared & 0.18 \\
\hline Observations & 810 \\
\hline Durbin-Watson & 1.74 \\
\hline F-Test, Firm Effects vs Pooled OLS (P-Value) (df) & $1.66(0.00)(91,717)$ \\
\hline F-Test, Adding Year Effects vs One-Way Model (P-Value) (df) & $1.51(0.06)(22,695)$ \\
\hline
\end{tabular}




\section{References}

[1] Brewers Association, BA (2021).

Available at: http://www.brewersassociation.org

[2] Spence, M. (1973). Job market signaling. Quarterly Journal of Economics 87, pp. 355-374.

[3] Spence, M. (2002). Signaling in retrospect and the informational structure of markets. American Economic Review 92, pp. 434-459.

[4] Great American Beer Festival, GABF (2021). About the beer competition. Available at http://www.greatamericanbeerfestival.com

[5] Meyer, J. (2019). Is Great American Beer Festival still a big deal for the beer world? Boulder Daily Camera October, 3, 2019.http://www.dailycamera.com.

[6] Kunce, M. (2021). Impacts on U.S. beer production: Evidence from state panel data 2008-2019. Journal of Applied Economics and Business 9(1), pp. 5-16.

[7] Kirmani, A. and Rao, A. R. (2000). No pain, no gain: A critical review of the literature on signaling unobservable product quality. Journal of Marketing 64(2), pp. 66-79.

[8] Connelly, B., Certo, S., Ireland, R. and Reutzel, C. (2011). Signaling theory: A review and assessment. Journal of Managment 37(1), pp. 39-67.

[9] Ackerberg, D. A. (2003). Advertising, learning, and consumer choice in experience good markets: an empirical examination. International Economic Review 44(3), pp. 1007-1040.

[10] Bagwell, K. (2007). The economic analysis of advertising. Handbook of Industrial Organization 3, pp. 1701-1844. Amsterdam: Elsevier.

[11] Yang, X. (2021). Estimating production functions when output prices and quality are unobservable. Pennsylvania State University at Altoona, Working Paper.

[12] Friberg, R. and Grönqvist, E. (2012). Do expert reviews affect the demand for wine? American Economic Journal: Applied Economics 4(1), pp. 193-211.

[13] Elzinga, K., Tremblay, C. and Tremblay, V. (2015). Craft beer in the United States: History, numbers, and geography. Journal of Wine Economics 10(3), pp. 242-274. Supplementary material and data link, http://dx.doi.org/10.1017/jwe.2015.22.

[14] Alworth, J. (2017). What do breweries get out of the GABF? Beervana Blog, Oct. 10, 2017. http://www.beervanablog.com 


\section{Appendix A}

Table A1: Pooled OLS and Two-Way Random Effects Estimates

\begin{tabular}{|l|l|c|}
\hline & \multicolumn{1}{|c|}{ OLS } & RE \\
\hline \multicolumn{3}{|c|}{ Total Sample } \\
\hline Constant (t) & $33.02(19.29)$ & $58.28(5.21)$ \\
\hline Medals (t) & $-5.23(-0.99)$ & $-3.75(-0.66)$ \\
\hline LM Test (P-Value) & na & $6.88(0.032)$ \\
\hline Hausman (P-Value) & na & $3.63(0.056)$ \\
\hline \multicolumn{3}{|c|}{ California } \\
\hline Constant (t) & $22.28(6.22)$ & $32.84(3.15)$ \\
\hline Medals (t) & $11.41(1.09)$ & $13.89(1.31)$ \\
\hline LM Test (P-Value) & na & $5.57(0.061)$ \\
\hline Hausman (P-Value) & na & $3.71(0.054)$ \\
\hline \multicolumn{2}{|l|}{ Colorado } \\
\hline Constant (t) & $33.12(3.09)$ & $53.81(2.14)$ \\
\hline Medals (t) & $21.20(0.84)$ & $20.19(0.82)$ \\
\hline LM Test (P-Value) & na & $5.12(0.077)$ \\
\hline Hausman (P-Value) & na & $3.48(0.062)$ \\
\hline \multicolumn{2}{|l|}{ Oregon } \\
\hline Constant (t) & $26.46(7.86)$ & $31.11(4.85)$ \\
\hline Medals (t) & $9.29(0.86)$ & $11.15(0.98)$ \\
\hline LM Test (P-Value) & na & $5.81(0.055)$ \\
\hline Hausman (P-Value) & na & $4.05(0.044)$ \\
\hline \multicolumn{2}{|l|}{ Wisconsin } \\
\hline Constant (t) & $34.51(4.26)$ & $34.45(2.86)$ \\
\hline Medals (t) & $7.15(0.28)$ & $11.29(0.42)$ \\
\hline LM Test (P-Value) & na & $5.22(0.074)$ \\
\hline Hausman (P-Value) & na & $3.72(0.054)$ \\
\hline
\end{tabular}




\title{
Appendix B
}

Directly quoted read-me file from supplements to Elzinga et al. (2015):

\author{
Database Documentation \\ "Craft Beer in the United States: History, Numbers, and Geography" \\ Kenneth Elzinga, Carol Horton Tremblay and Victor J. Tremblay \\ Journal of Wine Economics
}

The database for this paper consists of 3 files (one of which is in 2 formats):

Craft Brewer Capacity and Production-1979-1988.xlsx

Craft Brewer Production-1989-2012.xlsx

State Data on Craft Brewers-1979-2012.xlsx; State Data on Craft Brewers-1979-

2012.dta

The production and number of firms data for figures, maps and regressions were aggregated from the first two data sets, which consist of micro firm-level data. Figures contain data aggregated to the national level for the U.S., and maps and regressions are based on data aggregated to the state level. In defining "craft brewer" we include brewpubs, microbreweries and craft regionals but do not include contract brewers, national brewers and large regional brewers that were in existence before 1965. Units of measurement for production and capacity are 31gallon barrels except for the regression data where units of measurement are in 10,000 31-gallon barrels. The text, Table 3 and Appendix to the paper contain additional information regarding the data. The following describes each data set further.

\section{Craft Brewer Capacity and Production-1979-1988.xlsx}

This Excel file contains individual firm level data on craft beer company name, city, state abbreviation, zip code, capacity and production for 1979-1988. The file also contains state level data. Production for craft brewers is taken from data on the leading 100 firms produced by The Office of R.S. Weinberg, St. Louis. When production is missing for a particular brewer, it is estimated by: Production Estimate = capacity $\mathrm{x}$ mean capacity utilization rate. (Estimates are shown in the file in red.) The source for the capacity data is Brewers Digest, Brewery Directory, 1979-1989, which is published in January-February. The directory in year t (e.g., 1989) reflects capacity in year t-1 (1988).

\section{Craft Brewer Production-1989-2012.xlsx}

The source for this file is The New Brewer which contains individual firm level data on type of firm (micro, brewpub, regional), company name, state and production. 
The Excel file contains data for 1989-2012 which appears on multiple sheets, each sheet with data on 2 consecutive years. As mentioned above, contract brewers, national brewers, and large regional brewers that were in existence before 1965 have been deleted from the original source data.

State Data on Craft Brewers-1979-2012.xlsx; State Data on Craft Brewers-19792012.dta

The state-level data set is provided in both Excel and STATA formats. The dependent variables for the regressions, production and number of brewers, derive from the two craft brewer firm data sets listed above. The 50 states and the District of Columbia are included for a total of 1,683 observations. (Not all variables are available for 1979; the regression sample runs from 1980-2012). When Spatialfirms and Spatial-prod are used, the sample is limited to the continental U.S. and the number of observations is 1,617. These spatial variables are based on inverse distances between states, and Alaska and Hawaii are too distant from the other states to have reasonable values.

The Appendix in the paper contains source information for the regressors. The data set includes the state, state abbreviation, st, year, and the variables listed in Table 3 of the paper. All variables in the file are defined in Table 3 except for "st" which is a numeric value that identifies the state. The "st" variable does not correspond to any government designation but serves as a sort variable or numeric value for statements such as the "xtset" command in STATA. 